\title{
Correction: Nucleus accumbens medium spiny neurons subtypes signal both reward and aversion
}

\author{
Carina Soares-Cunha ${ }^{1,2}$ - Nivaldo A. P. de Vasconcelos ${ }^{1,2,3,4}$ - Bárbara Coimbra $\mathbb{C}^{1,2}$ - Ana Verónica Domingues ${ }^{1,2}$. \\ Joana M. Silva ${ }^{1,2} \cdot$ Eduardo Loureiro-Campos $^{1,2} \cdot$ Rita Gaspar $^{1,2,5,6} \cdot$ loannis Sotiropoulos $^{1,2} \cdot$ Nuno Sousa $\mathbb{D}^{1,2,7}$. \\ Ana João Rodrigues $\mathbb{( i D}^{1,2,7}$
}

Published online: 18 September 2019

(c) The Author(s) 2019. This article is published with open access

\section{Correction to: Molecular Psychiatry \\ https://doi.org/10.1038/s41380-019-0484-3 \\ published online 28 August 2019}

Following publication of this article, the authors noticed that the Supplementary Figures file was accidentally omitted. This file has now been uploaded alongside the original article. This has been corrected in both the PDF and HTML versions of the article.
Open Access This article is licensed under a Creative Commons Attribution 4.0 International License, which permits use, sharing, adaptation, distribution and reproduction in any medium or format, as long as you give appropriate credit to the original author(s) and the source, provide a link to the Creative Commons license, and indicate if changes were made. The images or other third party material in this article are included in the article's Creative Commons license, unless indicated otherwise in a credit line to the material. If material is not included in the article's Creative Commons license and your intended use is not permitted by statutory regulation or exceeds the permitted use, you will need to obtain permission directly from the copyright holder. To view a copy of this license, visit http://creativecommons. org/licenses/by/4.0/.

Nuno Sousa

njcsousa@med.uminho.pt

$\triangle$ Ana João Rodrigues

ajrodrigues@med.uminho.pt

1 Life and Health Sciences Research Institute (ICVS), School of Medicine, University of Minho, Braga, Portugal

2 ICVS/3B's-PT Government Associate Laboratory, Braga/ Guimarães, Portugal

3 Physics Department, Federal University of Pernambuco (UFPE), Recife, Pernambuco 50670-901, Brazil

4 Department of Biomedical Engineering, Federal University of Pernambuco (UFPE), Recife, Pernambuco 50670-901, Brazil

5 Coimbra Institute for Clinical and Biomedical Research (iCBR), Faculty of Medicine, University of Coimbra, Coimbra, Portugal

6 Center for Innovation in Biomedicine and Biotechnology (CIBB), University of Coimbra, Coimbra, Portugal

7 Clinical Academic Center-Braga (2CA), Braga, Portugal 